\title{
Abrogation of the p16-retinoblastoma-cyclin D1 pathway in head and neck squamous cell carcinomas
}

\author{
HUN-WOONG PARK ${ }^{1}$, SI-YOUN SONG ${ }^{1}$, TAE-JIN LEE ${ }^{2}$, DAEWON JEONG ${ }^{2}$ and TAE-YOON LEE ${ }^{2}$ \\ Departments of ${ }^{1}$ Otolaryngology and ${ }^{2}$ Microbiology, College of Medicine, Yeungnam \\ University, 317-1 Daemyung-dong, Namgu, Daegu 705-717, Korea
}

Received February 14, 2007; Accepted March 22, 2007

\begin{abstract}
In the present study, we analyzed p16, retinoblastoma (Rb), and cyclin D1 abnormalities in head and neck squamous cell carcinoma (HNSCC) tissues and cell lines from Korean patients. We found a $40 \%$ loss of heterozygosity at the D9S171 locus (9p21 region) these tissues. All eight of the HNSCC cell lines did not express the p16 protein, and in two of these cell lines (Amc-HN-6 and 8), this was due to a deletion of the p16 gene. Three of the cell lines (Amc-HN-3 to 5) that expressed the p16 mRNA had the same nonsense mutation at codon 50 (CGA-Arg to TGA-Ter). The AmcHN-1 and Amc-HN-7 cell lines, which did not express the p16 mRNA, had a missense mutation at codon 9 (GCC-Ala to GTC-Val) and a silent mutation at codon 106 (CCC-Pro to CCA), respectively. The Amc-HN-2 cell line (p16 exonpositive/mRNA-negative) had a single base deletion at codon 38 (CGG-Arg to CG), which resulted in a frameshift and a consequent stop signal at codon 44 . The $\mathrm{Rb}$ protein was detected in all of the eight cell lines, although it was inactive in five of these due to hyperphosphorylation. The inverse relationship between p16 and Rb was $62.5 \%$ (5/8). Cyclin D1 was overexpressed in all of the eight cell lines. Our results suggest that the abrogation of $\mathrm{p} 16$, the overexpression of cyclin $\mathrm{D} 1$, and the consequent inactivation of $\mathrm{Rb}$ could be important factors in the carcinogenesis of HNSCCs.
\end{abstract}

\section{Introduction}

Head and neck squamous cell carcinoma (HNSCC) remains a significant cause of morbidity and mortality, with $\sim 540,000$

Correspondence to: Dr Tae-Yoon Lee, Department of Microbiology, College of Medicine, Yeungnam University, 317-1 Daemyungdong, Namgu, Daegu 705-717, Korea

E-mail: doxr7p@med.yu.ac.kr

Abbreviations: HNSCC, head and neck squamous cell carcinoma; $\mathrm{Rb}$, retinoblastoma; CDK, cyclin-dependent kinase; $\mathrm{LOH}$, loss of heterozygosity; PBL, peripheral blood lymphocyte; RPA, ribonuclease protection assay

Key words: head and neck squamous cell carcinoma, p16, retinoblastoma, cyclin D1, alteration new cases reported annually worldwide and 271,000 deaths reported annually resulting in a mortality rate of $50 \%$ (1). HNSCC is the most common cancer in head and neck malignancies and it is the sixth most common cancer worldwide (2). HNSCC ranks 5th in both the frequency and cause of cancer death in Western countries (3). HNSCC is very common, especially in India and South East Asia, and accounts for $\sim 40 \%$ of all malignancies (4).

The retinoblastoma $(\mathrm{Rb})$ protein is one of the most important cell cycle proteins of the G1 checkpoint. The activity of the $\mathrm{Rb}$ protein is regulated by its phosphorylation level, which is mediated by cell cycle regulators such as p16 and cyclin D1.

The tumor suppressor gene, p16 (MTS1/CDKN2A), located on human chromosome $9 \mathrm{p} 21$, encodes a protein that inhibits the binding of cyclin D1 to the cyclin-dependent kinases (CDK4 or CDK6), thus preventing the phosphorylation of the $\mathrm{Rb}$ protein $(5,6)$. The underphosphorylated $\mathrm{Rb}$ inhibits the E2F-mediated transcriptional activation of the $S$ phase genes, which are necessary for cell proliferation. The p16 protein is one of the central $\mathrm{Rb}$-dependent regulators responsible for controlling cell proliferation at the G1-S checkpoint.

The cyclin D1 proto-oncogene is also a key regulator of the cell cycle at the restriction point in late G1. Cyclin D1 binds to CDK4/6 and subsequently induces cell proliferation by releasing the $\mathrm{E} 2 \mathrm{~F}$ transcription factor from the $\mathrm{Rb}$ protein via the phosphorylation of $\mathrm{Rb}$ (7-9). The amplification of the cyclin D1 gene and protein overexpression have been associated with aggressive behavior in HNSCC and other tumors including higher local recurrence, higher metastatic potential, and diminished survival (10-14).

The inactivation of p16, the overexpression of cyclin D1, and the subsequent inactivation of the $\mathrm{Rb}$ protein have been reported in a variety of human cancers (15-20). However, little is known about the p16-Rb-cyclin D1 status in HNSCC in Korean patients. Thus, this study sought to determine whether $\mathrm{p} 16, \mathrm{Rb}$, and cyclin D1 alterations are important in the development of HNSCCs in a Korean population. We performed a loss of heterozygosity ( $\mathrm{LOH}$ ) analysis of eight Korean HNSCCs using nine microsatellite markers that cover chromosome 9p. We also examined eight HNSCC cell lines obtained from Korean patients, in order to reveal alterations in the p16 gene and protein expressions of p16, Rb, and cyclin D1. We discuss the correlation between $\mathrm{p} 16, \mathrm{Rb}$, and cyclin D1 and the implication of such correlations in the carcinogenesis of HNSCC in Korean patients. 
Table I. Microsatellite markers on chromosome 9p for LOH analysis.

\begin{tabular}{|c|c|c|c|}
\hline Marker & Primer & Sequence (5' to $\left.3^{\prime}\right)$ & Location \\
\hline D9S144 & $\begin{array}{l}\text { 9CMP4R } \\
9 \mathrm{CMO} 4 \mathrm{~F}\end{array}$ & $\begin{array}{l}\text { GGATAAATACACTGGAAAAGAGAT } \\
\text { AAATATTATAGCAAGTTAATTACTGAA }\end{array}$ & 9pter-p22 \\
\hline D9S156 & $\begin{array}{l}\text { AFM051xd6m } \\
\text { AFM051xd6a }\end{array}$ & $\begin{array}{l}\text { AGATGGTGGTGAATAGAGGG } \\
\text { ATCACTTTTAACTGAGGCGG }\end{array}$ & $9 \mathrm{p} 23-\mathrm{p} 22$ \\
\hline D9S162 & $\begin{array}{l}\text { AFM115yb4m } \\
\text { AFM115yb4a }\end{array}$ & $\begin{array}{l}\text { AATTCCCACAACAAATCTCC } \\
\text { GCAATGACCAGTTAAGGTTC }\end{array}$ & $9 \mathrm{p} 23-\mathrm{p} 22$ \\
\hline D9SIFNA & $\begin{array}{l}\text { GT strand } \\
\text { AC strand }\end{array}$ & $\begin{array}{l}\text { TGCGCGTTAAGTTAATTGGTT } \\
\text { GTAAGGTGGAAACCCCCACT }\end{array}$ & 9 p22 \\
\hline D9S171 & $\begin{array}{l}\text { AFM186xc3m } \\
\text { AFM186xc3a }\end{array}$ & $\begin{array}{l}\text { ACCCTAGCACTGATGGTATAGTCT } \\
\text { AGCTAAGTGAACCTCATCTCTGTCT }\end{array}$ & $9 \mathrm{p} 21$ \\
\hline D9S126 & $\begin{array}{l}\text { D9S126.PCR1.2 } \\
\text { D9S126.PCR1.1 }\end{array}$ & $\begin{array}{l}\text { CAACTCCTCTTGGGAACTGC } \\
\text { ATTGAAACTCTGCTGAATTTTCTG }\end{array}$ & $9 \mathrm{p} 21$ \\
\hline D9S161 & $\begin{array}{l}\text { AFM087yd3m } \\
\text { AFM087yd3a }\end{array}$ & $\begin{array}{l}\text { CATGCCTAGACTCCTGATCC } \\
\text { TGCTGCATAACAAATTACCAC }\end{array}$ & 9 p21 \\
\hline D9S200 & $\begin{array}{l}\text { C80R } \\
\text { C80F }\end{array}$ & $\begin{array}{l}\text { ССТСТСТGCATGCCCCAG } \\
\text { GCATTTCACAGGAAATAATCTAAGG }\end{array}$ & $9 \mathrm{p} 21-\mathrm{p} 12$ \\
\hline D9S166 & $\begin{array}{l}\text { AFM144zg7m } \\
\text { AFM144zg7a }\end{array}$ & $\begin{array}{l}\text { TCCTAATTCACTGGGAAAAC } \\
\text { AАATCATGCAATTCATTTCA }\end{array}$ & $9 p 12-q 21$ \\
\hline
\end{tabular}

\section{Materials and methods}

Tissues, peripheral blood lymphocyte $(P B L) s$, and DNA extraction. We used samples of 8 surgically resected HNSCCs and PBLs of the corresponding patients. The tissues and PBLs were snap frozen using liquid nitrogen and stored immediately at $-80^{\circ} \mathrm{C}$ until analysis. The genomic DNA from the microdissected tumor tissues and PBLs were prepared using a QIAamp Tissue Kit (Qiagen, Chatwirth, CA, USA).

LOH. LOH analysis was performed using 9 microsatellite markers spanning chromosome 9p. The microsatellite markers used in this study are shown in Table I. The primers were purchased from Research Genetics (Huntsville, AL, USA). PCR was carried out in $10 \mu 1$ reaction volumes that contained 100 ng genomic DNA, 1X PCR buffer (GibcoBRL, Grand Island, NY, USA), $100 \mu \mathrm{M}$ of each dATP, dGTP and dTTP, $5 \mu \mathrm{M} \mathrm{dCTP}, 1 \mu \mathrm{Ci}\left[\alpha-{ }^{32} \mathrm{P}\right] \mathrm{dCTP}, 2.5 \mathrm{pmol}$ of each primer, and 1 unit Taq polymerase (Perkin-Elmer, Sunnyville, CA, USA). PCR was performed in a Thermocycler 9600 (Perkin-Elmer) under the following conditions: Initial denaturation at $94^{\circ} \mathrm{C}$ for 2 min followed by 30 amplification cycles $\left(94^{\circ} \mathrm{C}\right.$ for $30 \mathrm{sec}, 58^{\circ} \mathrm{C}$ for $30 \mathrm{sec}$, and $72^{\circ} \mathrm{C}$ for $\left.30 \mathrm{sec}\right)$, and a final extension at $72^{\circ} \mathrm{C}$ for $7 \mathrm{~min}$. The PCR product was separated on a denaturing polyacrylamide gel and the bands were detected by autoradiography. LOH was scored when the intensity of one allele was absent or at least $70 \%$ reduced in the tumor alleles when compared to the corresponding wildtype alleles for the informative cases. Any additional bands on the tumor side were regarded as microsatellite instability.
Cell lines and preparation of genomic DNA and total RNA. Eight HNSCC cell lines from Korean patients, Amc-HN-1, Amc-HN-2, Amc-HN-3, Amc-HN-4, Amc-HN-5, Amc-HN-6, Amc-HN-7, and Amc-HN-8, were obtained from the Asan Biological Sciences Research Center at Ulsan University (Ulsan, Korea). The genomic DNA was isolated using a standard SDS-proteinase $\mathrm{K}$ and phenol-chloroform extraction method. The total RNA was extracted using an RNeasy Total RNA Kit (Qiagen).

Detection of p16 deletion. The p16 deletion was detected by PCR of exons 1 and 2 of the p16 gene using the following primers (exon 1: Forward, 5'-GGAATTCGAAGAAAGA-3' and reverse, 5'-CGGATCCTCTACCCACCTGGATCGG-3'; exon 2: Forward, 5'-GCTTCCTTTCCGTCATGCCG-3' and reverse, 5'-CAAATTCTCAGATCATC-3') and Vent DNA polymerase (New England Biolabs, Beverly, MA, USA). The PCR products were resolved on a $10 \%$ polyacrylamide gel and stained with ethidium bromide.

Nucleotide sequence determination of the pl6 gene. Exons 1 and 2 of the p16 gene in the Amc-HN-series HNSCC cell lines amplified by Vent polymerase (New England Biolabs), were cloned into the HincII site of pUC18. The nucleotide sequence was determined using an automated sequencer (ABI PRISM 377, Perkin-Elmer, Norwalk, CT, USA).

Ribonuclease protection assay (RPA). RPA was performed using the Multi-probe RNase Protection Assay System (PharMingen, San Diego, CA, USA). Ten micrograms of total 


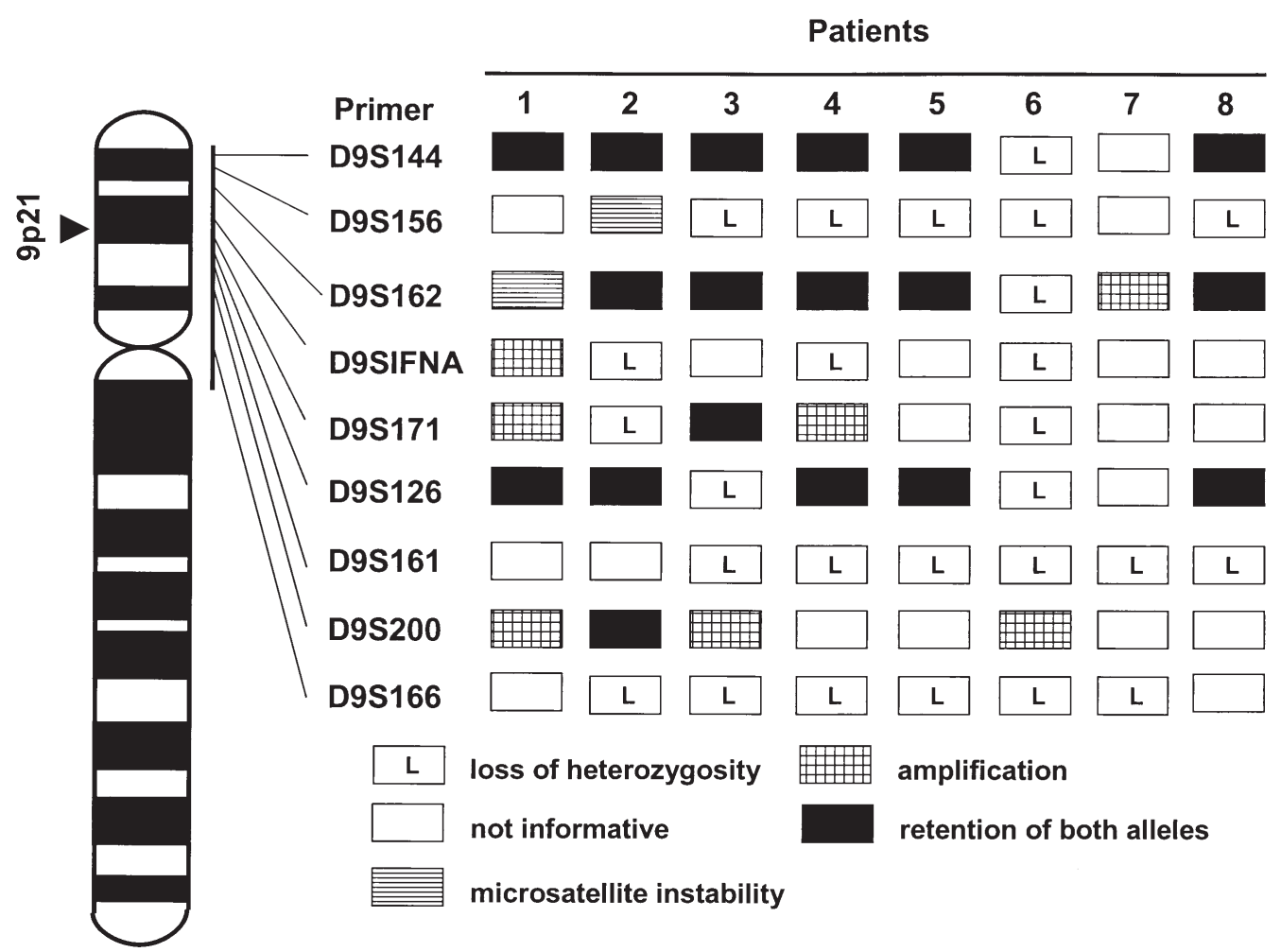

Figure 1. Deletion map of chromosome 9p. Microsatellite markers and map positions are illustrated. The arrow indicates the D9S171 (9p21) locus.

Table II. Summary of 9p allelic abnormalities in HNSCCs in Korean patients.

\begin{tabular}{lllll}
\hline Primer & \multicolumn{1}{c}{ Site } & $\begin{array}{c}\text { LOH/IC } \\
(\%)\end{array}$ & $\begin{array}{c}\text { AM/IC } \\
(\%)\end{array}$ & $\begin{array}{c}\text { MI/IC } \\
(\%)\end{array}$ \\
\hline D9S144 & 9 pter-p22 & $1 / 7(14.3)$ & $0 / 7(0)$ & $0 / 7(0)$ \\
D9S156 & $9 p 23-p 22$ & $5 / 6(83.3)$ & $0 / 6(0)$ & $2 / 6(33.3)$ \\
D9S162 & $9 p 23-p 22$ & $1 / 8(12.5)$ & $1 / 8(12.5)$ & $1 / 8(12.5)$ \\
D9SIFNA & $9 p 22$ & $3 / 4(75)$ & $1 / 4(25)$ & $0 / 4(0)$ \\
D9S171 & $9 p 21$ & $2 / 5(40)$ & $2 / 5(40)$ & $0 / 5(0)$ \\
D9S126 & $9 p 21$ & $2 / 7(28.6)$ & $0 / 7(0)$ & $0 / 7(0)$ \\
D9S161 & $9 p 21$ & $6 / 6(100)$ & $0 / 6(0)$ & $0 / 6(0)$ \\
D9S200 & $9 p 21-p 12$ & $0 / 4(0)$ & $3 / 4(75)$ & $0 / 4(0)$ \\
D9S166 & $9 p 21-q 21$ & $6 / 6(100)$ & $0 / 6(0)$ & $0 / 6(0)$ \\
\hline
\end{tabular}

IC, informative cases; AM, amplification; MI, microsatellite instability.

RNA were hybridized with p16 and Rb probes which were transcribed in vitro in the presence of the GACU nucleotide pool, RPA template set, RNasin, and $\left[\alpha^{-32} \mathrm{P}\right] \mathrm{UTP}$ (DuPont NEN, Boston, MA, USA) using the T7 polymerase according to the manufacturer's manual. The RNA duplexes protected from RNase treatment were isolated and electrophoresed in a standard $6 \%$ acrylamide gel containing $7 \mathrm{M}$ urea. The gel was dried and placed on an XAR film (Kodak, Rochester, $\mathrm{NY}$, USA) with intensifying screens and exposed at $-80^{\circ} \mathrm{C}$.
Preparation of nuclear extracts and Western blotting. The cells were harvested with trypsin-EDTA and washed with PBS. The cell pellets were resuspended in $400 \mu 1$ cold buffer A [10 mM Hepes-KOH (pH 7.9), $1.5 \mathrm{mM} \mathrm{MgCl}_{2}, 10 \mathrm{mM} \mathrm{KCl,}$ $0.5 \mathrm{mM}$ DTT, $0.1 \% \mathrm{NP}-40$, and $0.2 \mathrm{mM} \mathrm{PMSF}$ ] and allowed to swell on ice for $30 \mathrm{~min}$. The cells were then vortexed for $30 \mathrm{sec}$ and centrifuged for $10 \mathrm{sec}$. The pellet was resuspended in 1 to 3 vol cold buffer C [20 mM Hepes ( $\mathrm{pH} 7.9$ ), 25\% glycerol, $420 \mathrm{mM} \mathrm{NaCl}, 1.5 \mathrm{mM} \mathrm{MgCl}_{2}, 0.2 \mathrm{mM}$ EDTA, $0.5 \mathrm{mM}$ DTT, and $0.2 \mathrm{mM}$ PMSF] and incubated on ice for $30 \mathrm{~min}$. The cellular debris was removed by centrifugation for $2 \mathrm{~min}$ at $4^{\circ} \mathrm{C}$. Forty micrograms of the nuclear extracts were separated on a 4-20\% gradient SDS-polyacrylamide gel (Novex, San Diego, CA, USA). The protein transferred onto the nitrocellulose membrane was probed with $\mathrm{p} 16, \mathrm{Rb}$ or cyclin D1-specific antibodies (PharMingen).

\section{Results and Discussion}

LOH at region 9p in HNSCC tissues. LOH at D9S171 (region 9p21) was found in 2 of 5 cases (40\%; Fig. 1 and Table II). Although only 5 cases were informative, this result suggests that the genetic alteration(s) near or including the p16 tumor suppressor gene occurred during the development of HNSCCs. This frequency of LOH was higher than the LOH frequencies of $15 \%$ (21) and $19 \%$ (22) reported in previous studies. Other reports have shown a similar (41\%) (23) or increased (75\%) (24) LOH at 9p21 in HNSCC. Other markers exhibiting a high frequency of LOH were D9S161 $(100 \%, 6$ of 6$)$, D9S166 (100\%, 6 of 6), D9S156 (83\%, 5 of $6)$, and D9SIFNA $(75 \%, 3$ of 4$)$. This suggests that an extensive genetic alteration occurred in many loci on chromo- 


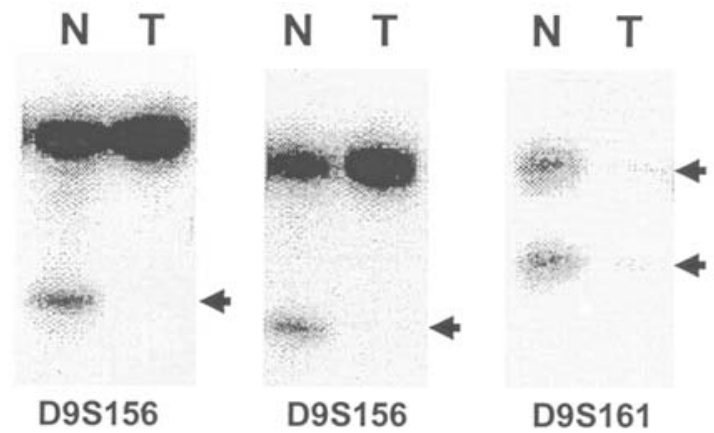

Figure 2. Representative LOH patterns. T, HNSCC tissue; N, corresponding PBL of the same patient. The arrows indicate the absence or a decreased band intensity of over $70 \%$ in the HNSCC tissues.

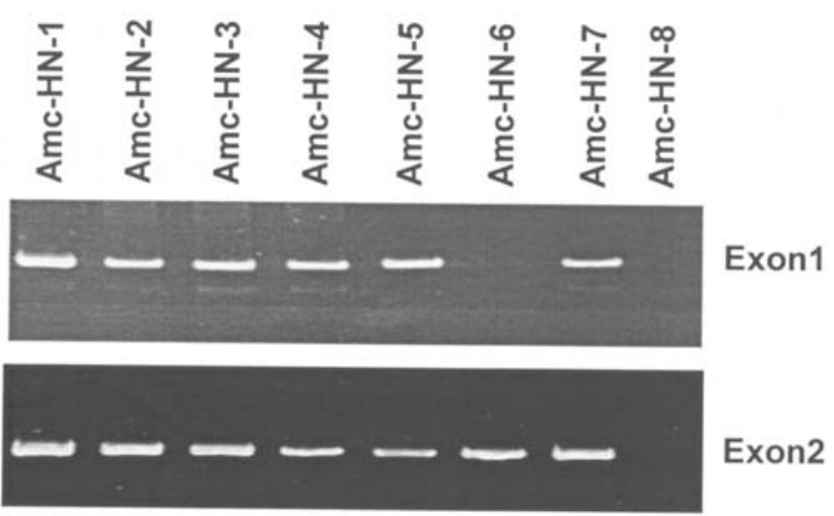

Figure 3. The p16 gene deletion in the HNSCC cell lines. The PCR analyses amplifying p16 exons 1 and 2 were performed with genomic DNAs from the cell lines.

some 9p during the carcinogenesis of HNSCC. For example, patient No. 6 showed LOH in 8 of the 9 microsatellite markers. Representative $\mathrm{LOH}$ patterns are shown in Fig. 2. We further characterized the alterations of p16 in the 8 HNSCC cell lines from Korean patients.

P16 alterations. Two cell lines (Amc-HN-6 and Amc-HN-8) had a deletion in exon 1 of the p16 gene. The Amc-HN-8 cell line contained deletions in both exons 1 and 2 (Fig. 3). We could not detect p16 transcripts in these 2 cell lines by RPA analysis. Amc-HN-1, Amc-HN-2, and Amc-HN-7, which were shown to contain p16 exons 1 and 2, did not express the p16 transcripts (Fig. 4). Amc-HN-3, Amc-HN-4, and AmcHN-5, which did show the p16 transcripts, did not express the p16 protein. These results suggest that these 6 cell lines contained mutations in or around the p16 gene. All of the 8 HNSCC cell lines examined did not express the p16 protein (Fig. 4).

Zhang et al (25) and Lydiatt et al (22) reported that the frequency of p16 deletions and mutations in HNSCC cell lines was 44 and $56.2 \%$, respectively. In this study, we found that genetic alterations in 16 are less frequent in primary HNSCC tissues (40\%) than in the HNSCC cell line (100\%). This could be due to the fact that p16 deletions result from adaptation to the tissue culture, as suggested by other investigators who found relatively low frequencies of p16

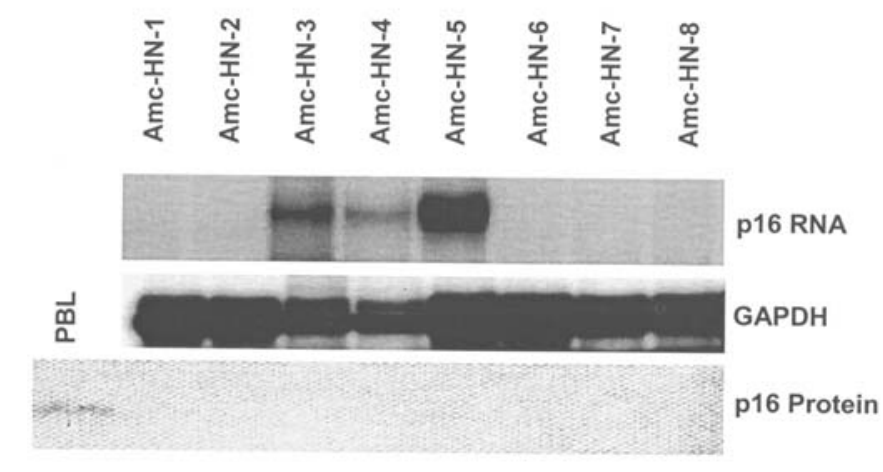

Figure 4. Alterations of the p16 mRNA and protein detected by RPA and Western blotting in the HNSCC cell lines. GAPDH, glyceraldehyde-3-phosphate dehydrogenase mRNA.

alterations in primary tumors in comparison to cell lines (26). Alternatively, the lower frequency of the p16 alteration could result from the high sensitivity of the PCR-based assay, which allows for a positive reaction even in the presence of an extremely small amount of normal tissue contamination.

The p16 mutations in HNSCC cell lines. We then determined the nucleotide sequence of p16 exons 1 and 2 in the HNSCC cell lines (Amc-HN-1, Amc-HN-2, Amc-HN-3, Amc-HN-4, Amc-HN-5, and Amc-HN-7). Amc-HN-1, Amc-HN-2, and Amc-HN-7 were p16 DNA-positive/p16 RNA-negative, while Amc-HN-3, Amc-HN-4, and Amc-HN-5 were p16 DNA-positive/p16 RNA-positive/p16 protein-negative. AmcHN-1 had a missense mutation at codon 9 (GCC-Ala to GTC-Val) of exon 1. Amc-HN-2 had a single base deletion at codon 38 (CGG-Arg to CG) of exon 1, which resulted in a frameshift and consequent stop signal at codon 44 . Amc-HN-7 had a silent mutation at codon 106 (CCC-Pro to CCA) of exon 2. Amc-HN-3, Amc-HN-4, and Amc-HN-5 all contained a nonsense mutation at the same site (codon 50, CGA-Arg to TGA-Ter) of exon 2. This mutation could result in the truncation of the p16 protein, which may not be detected by Western blotting. The same mutation was reported by Poi et al (27) and by Tripathi et al (28) in HNSCC and cervical carcinoma, respectively. The missense mutation at codon 9 (Amc-HN-1), the single base deletion at codon 38 (Amc-HN2), and the silent mutation at codon 106 (Amc-HN-7), have not been previously reported.

Since the mutations in Amc-HN-1 and Amc-HN-7 did not affect the protein function, the absence of p16 mRNA in these cell lines could be due to unknown mechanisms including p16 promoter methylation.

$R b$ alterations. Our next step was to analyze $\mathrm{Rb}$ expression since p16 controls cell proliferation via the Rb pathway. $\mathrm{Rb}$ was detected in all the 8 cell lines examined at both the mRNA and protein levels. We examined the phosphorylation status of Rb using an Rb-specific antibody that can detect both hyperphosphorylated and hypophosphorylated Rb. Five cell lines (Amc-HN-1, Amc-HN-4, Amc-HN-5, Amc-HN-7, and Amc-HN-8) expressed hyperphosphorylated (inactive) $\mathrm{Rb}$ (Fig. 5). This suggests that the abrogation of p16 and the consequent inactivation of $\mathrm{Rb}$ could be important in the 


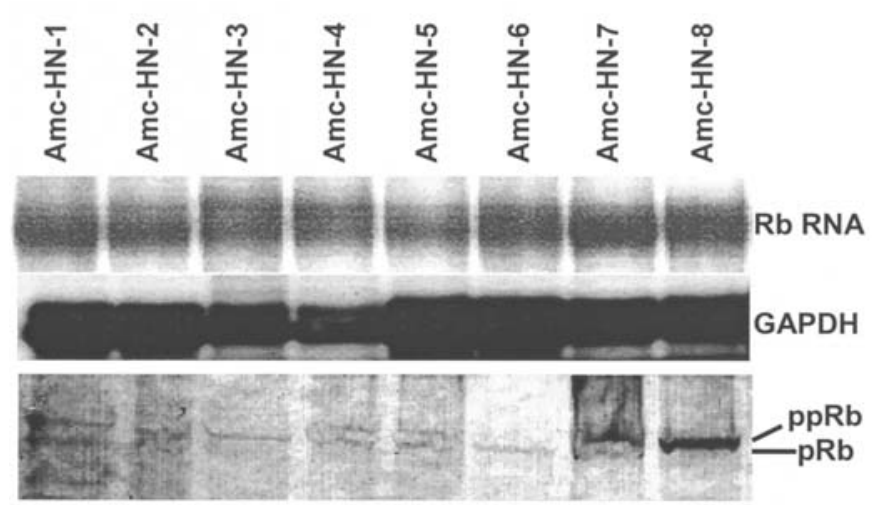

Figure 5. mRNA and protein alterations of Rb detected by RPA and Western blotting in the HNSCC cell lines. Western blotting was performed with a monoclonal antibody that detects both hyperphosphorylated (ppRb) and hypophosphorylated (pRb) Rb proteins.

carcinogenesis of HNSCCs. The inverse relationship between p16 and $\mathrm{Rb}$ was $62.5 \%(5 / 8)$.

Cyclin D1 overexpression. Cyclin D1 is deregulated in many types of human tumor cells. The overexpression of cyclin D1 was especially known to contribute to the oncogenic transformation of cells (29-31). The expression level of cyclin D1 affects cell proliferation through binding to CDK4 and CDK6. Thus, we analyzed cyclin D1 protein expression using Western blotting. Cyclin D1 was overexpressed in all the HNSCC cell lines examined in comparison to the expression levels of normal PBLs (Fig. 6). The elevated cyclin D1 level induced the hyperphosphorylation of the $\mathrm{Rb}$ proteins in the

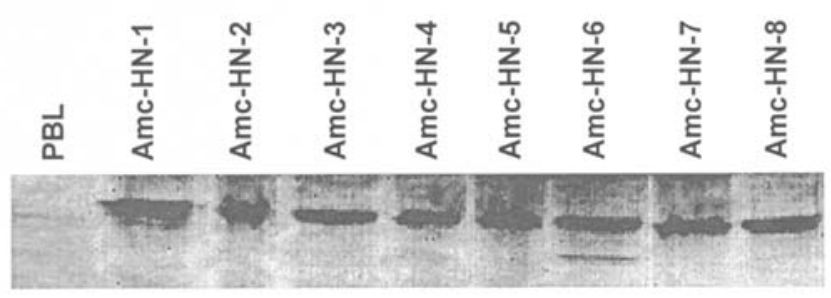

Figure 6. The overexpression of cyclin D1 detected by immunoblotting in the HNSCC cell lines. The leftmost lane shows the cyclin D1 expression level of normal PBLs with the same protein loading.

HNSCC cell lines in the absence of the p16 protein. All of the eight HNSCC cell lines that did not express the p16 protein expressed cyclin D1 at a high level. This was consistent with the report that the loss of p16 in tumor cells is related to constitutive cyclin D1 expression (32).

Cyclin D1 overexpression has been reported to supersede $\mathrm{Rb}$-mediated growth inhibition in esophageal tumors and in small cell lung carcinoma $(13,33)$. This could be related to the phosphorylation and inactivation of the $\mathrm{Rb}$ gene product or to the growth-promoting activity by cyclin $\mathrm{D} 1$, independent of $\mathrm{Rb}$ (33). These reports could explain our finding that the active proliferative properties of the $3 \mathrm{HNSCC}$ cell lines (Amc-HN-2, Amc-HN-3, and Amc-HN-6) expressing active (hypophosphorylated) Rb, were due to the cyclin D1 overexpression. The alterations of $\mathrm{p} 16, \mathrm{Rb}$, and cyclin D1 in the HNSCC cell lines studied are summarized in Table III. All of the $8(100 \%)$ HNSCC cell lines did not express the p16 proteins, and in $2(25 \%)$ and $4(50 \%)$ of these cell lines, this was due to p16 homozygous deletions and mutations,

Table III. Summary of p16, Rb, and cyclin D1 alterations in HNSCC cell lines in Korean patients.

\begin{tabular}{|c|c|c|c|c|c|c|c|c|}
\hline \multirow[b]{2}{*}{ Cell lines } & \multicolumn{4}{|c|}{ p16 } & \multicolumn{3}{|c|}{$\mathrm{Rb}$} & \multirow[b]{2}{*}{ CycD1 } \\
\hline & DNA & RNA & Protein & Mutation & RNA & $\mathrm{ppRb}$ & $\mathrm{pRb}$ & \\
\hline Amc-HN-1 & + & - & - & $\begin{array}{l}\text { 9th } \mathrm{GCC}_{\mathrm{Ala}} \\
\text { to } \mathrm{GTC}_{\mathrm{Val}}\end{array}$ & + & + & + & + \\
\hline Amc-HN-2 & + & - & - & $\begin{array}{l}\text { 38th } \mathrm{CGG}_{\mathrm{Arg}} \\
\text { to } \mathrm{CG}(\mathrm{G} \text { deletion }) \\
\text { stop at } 44 \text { th codon }\end{array}$ & + & - & + & + \\
\hline Amc-HN-3 & + & + & - & $\begin{array}{l}\text { 50th } \mathrm{CGA}_{\mathrm{Arg}} \\
\text { to } \mathrm{TGA}_{\mathrm{Ter}}\end{array}$ & + & - & + & + \\
\hline Amc-HN-4 & + & + & - & $\begin{array}{l}\text { 50th } \mathrm{CGA}_{\mathrm{Arg}} \\
\text { to } \mathrm{TGA}_{\mathrm{Ter}}\end{array}$ & + & + & + & + \\
\hline Amc-HN-5 & + & + & - & $\begin{array}{l}\text { 50th } \mathrm{CGA}_{\mathrm{Arg}} \\
\text { to } \mathrm{TGA}_{\mathrm{Ter}}\end{array}$ & + & + & + & + \\
\hline Amc-HN-6 & - & - & - & ND & + & - & + & + \\
\hline Amc-HN-7 & + & - & - & $\begin{array}{l}\text { 106th } \mathrm{CCC}_{\text {Pro }} \\
\text { to } \mathrm{CCA}_{\text {Pro }}\end{array}$ & + & + & + & + \\
\hline Amc-HN-8 & - & - & - & ND & + & + & + & + \\
\hline
\end{tabular}

ppRb, Hyperphosphorylated Rb; pRb, hypophosphorylated Rb; CycD1, cyclin D1 overexpression; ND, not determined. 
respectively. The absence of the p16 protein (100\%) and the overexpression of cyclin D1 (100\%) were related to the hyperphosphorylation (inactivation, $63 \%$ ) of the $\mathrm{Rb}$ proteins.

In this study, we showed the alterations in the p16-Rbcyclin D1 tumor-suppressive pathway in HNSCCs in Korean patients. Our results suggest that the loss of the p16 protein, cyclin D1 overexpression, and the consequent inactivation of the $\mathrm{Rb}$ proteins, are important factors in the development of HNSCCs.

\section{Acknowledgements}

We thank Dr Sang-Youn Kim (Ulsan University, Ulsan, Korea) for kindly providing the HNSCC cell lines.

\section{References}

1. Stewart BW and Kleihues P: WHO World Cancer Report. International Agency for Research on Cancer, Geneva, pp232-236, 2003.

2. Parkin DM, Pisani P and Ferlay J: Global cancer statistics. CA Cancer J Clin 49: 33-64, 1999.

3. Dobrossy L: Epidemiology of head and neck cancer: magnitude of the problem. Cancer Metastasis Rev 24: 9-17, 2005.

4. Saranath D, Bhoite LT and Deo MG. Molecular lesions in human oral cancers: the Indian scene. Oral Oncol 29B: 107-112, 1993.

5. Kamb A, Gruis NA, Weaver-Feldhaus J, Liu Q, Harshman K, Tavtigian SV, Stockert E, Day RS III, Johnson BE and Skolnick MH: A cell-cycle regulator potentially involved in genesis of many tumor types. Science 264: 436-440, 1994.

6. Sherr CJ: Cancer cell cycles. Science 274: 1672-1677, 1996.

7. Motokura T and Arnold A: Cyclins and oncogenesis. Biochim Biophys Acta 1155: 63-78, 1993.

8. Bartkova J, Lukas J, Muller H, Strauss M, Gusterson B and Bartek J: Abnormal patterns of D-type cyclin expression and G1 regulation in human head and neck cancer. Cancer Res 55: 949-956, 1995.

9. Maelandsmo GM, Florenes VA, Hovig E, Oyjord T, Engebraaten O, Holm R, Borresen AL and Fodstad O: Involvement of the $\mathrm{pRb} / \mathrm{p} 16 / \mathrm{cdk} 4 /$ cyclin $\mathrm{D} 1$ pathway in the tumorigenesis of sporadic malignant melanomas. Br J Cancer 73: 909-916, 1996.

10. Jiang W, Zhang YJ, Kahn SM, Hollstein MC, Santella RM, Lu SH, Harris CC, Montesano R and Weinstein IB: Altered expression of the cyclin D1 and retinoblastoma genes in human esophageal cancer. Proc Natl Acad Sci USA 90: 9026-9030, 1993.

11. Motokura T, Bloom T, Kim HG, Juppner H, Ruderman JV, Kronenberg HM and Arnold A: A novel cyclin encoded by a bcl-linked candidate oncogene. Nature 350: 512-515, 1991.

12. Williams ME, Gaffey MJ, Weiss LM, Wilczynski SP, Schuuring E and Levine PA: Chromosome 11Q13 amplification in head and neck squamous cell carcinoma. Arch Otolaryngol Head Neck Surg 119: 1238-1243, 1993.

13. Jares P, Fernandez PL, Campo E, Nadal A, Bosch F, Aiza G, Nayach I, Traserra J and Cardesa A: PRAD-1/cyclin D1 gene amplification correlates with messenger RNA overexpression and tumor progression in human laryngeal carcinomas. Cancer Res 54: 4813-4817, 1994.

14. El-Naggar AK, Steck K and Batsakis JG: Heterogeneity of the proliferative fraction and cyclin D1/CCND1 gene amplification in head and neck squamous cell carcinoma. Cytometry 21: 47-51, 1995.

15. Nobori T, Miura K, Wu DJ, Lois A, Takabayashi K and Carson DA: Deletions of the cyclin-dependent kinase-4 inhibitor gene in multiple human cancers. Nature 368: 753-756, 1994.

16. Mori T, Miura K, Aoki T, Nishihira T, Mori S and Nakamura Y: Frequent somatic mutation of the MTS1/CDK4I (multiple tumor suppressor/cyclin-dependent kinase 4 inhibitor) gene in esophageal squamous cell carcinoma. Cancer Res 54: 3396-3397, 1994.
17. Okamoto A, Demetrick DJ, Spillare EA, Hagiwara K, Hussain SP, Bennett WP, Forrester K, Gerwin B, Serrano M, Beach DH and Harris CC: Mutations and altered expression of $\mathrm{p} 16^{\mathrm{INK} 4}$ in human cancer. Proc Natl Acad Sci USA 91: 11045-11049, 1994.

18. Cairns P, Polascik TJ, Eby Y, Tokino K, Califano J, Merlo A, Mao L, Herath J, Jenkins R, Westra W, Rutter JL, Buckler A, Gabrielson E, Tockman M, Cho KR, Hedrick L, Bova GS, Isaacs W, Koch W, Schwab D and Sidransky D: Frequency of homozygous deletion at $\mathrm{p} 16 / \mathrm{CDKN} 2$ in primary human tumors. Nat Genet 11: 210-212, 1995.

19. Bartkova J, Lukas J, Guldberg P, Alsner J, Kirkin AF, Zeuthen J and Bartek J: The p16-cyclin D/Cdk4-pRb pathway as a functional unit frequently altered in melanoma pathogenesis. Cancer Res 56: 5475-5483, 1996.

20. Reed AL, Califano J, Cairns P, Westra WH, Jones RM, Koch W, Ahrendt S, Eby Y, Sewell D, Nawroz H, Bartek J and Sidransky D: High frequency of p16 (CDKN2/MTS-1/INK4A) inactivation in head and neck squamous cell carcinoma. Cancer Res 56: 3630-3633, 1996.

21. Weber A, Langhanki L, Schutz A, Wittekind C, Bootz F and Tannapfel A: Alterations of the INK4a-ARF gene locus in pleomorphic adenoma of the parotid gland. J Pathol 198: 326-334, 2002.

22. Lydiatt WM, Murty VV, Davidson BJ, Xu L, Dyomina K, Sacks PG, Schantz SP and Chaganti RS: Homozygous deletions and loss of expression of the CDKN2 gene occur frequently in head and neck squamous cell carcinoma cell lines but infrequently in primary tumors. Genes Chromosomes Cancer 13: $94-98,1995$.

23. Gruttgen A, Reichenzeller M, Junger M, Schlien S, Affolter A and Bosch FX: Detailed gene expression analysis but not microsatellite marker analysis of 9p21 reveals differential defects in the INK4a gene locus in the majority of head and neck cancers. J Pathol 194: 311-317, 2001.

24. Gonzalez MV, Pello MF, Lopez-Larrea C, Suarez C, Menendez MJ and Coto E: Loss of heterozygosity and mutation analysis of the p16 (9p21) and p53 (17p13) genes in squamous cell carcinoma of the head and neck. Clin Cancer Res 1: 1043-1049, 1995.

25. Zhang YJ, Jiang W, Chen CJ, Lee CS, Kahn SM, Santella RM and Weinstein IB: Amplification and overexpression of cyclin D1 in human hepatocellular carcinoma. Biochem Biophys Res Commun 196: 1010-1016, 1993.

26. Cairns P, Mao L, Merlo A, Lee DJ, Schwab D, Eby Y, Tokino K, van der Riet P, Blaugrund JE and Sidransky D: Rates of p16 (MTS1) mutations in primary tumors with 9p loss. Science 265: 415-417, 1994.

27. Poi MJ, Yen T, Li J, Song H, Lang JC, Schuller DE, Pearl DK, Casto BC, Tsai MD and Weghorst CM: Somatic INK4a-ARF locus mutations: a significant mechanism of gene inactivation in squamous cell carcinomas of the head and neck. Mol Carcinog 30: 26-36, 2001

28. Tripathi A, Banerjee S, Roy A, Roychowdhury S and Panda CK: Alterations of the P16 gene in uterine cervical carcinoma from Indian patients. Int J Gynecol Cancer 13: 472-479, 2003.

29. Sherr CJ: Mammalian G1 cyclins. Cell 73: 1059-1065, 1993.

30. Gillett C, Fantl V, Smith R, Fisher C, Bartek J, Dickson C, Barnes D and Peters G: Amplification and overexpression of cyclin D1 in breast cancer detected by immunohistochemical staining. Cancer Res 54: 1812-1817, 1994.

31. Naitoh H, Shibata J, Kawaguchi A, Kodama M and Hattori T: Overexpression and localization of cyclin D1 mRNA and antigen in esophageal cancer. Am J Pathol 146: 1161-1169, 1995.

32. Parry D, Bates S, Mann DJ and Peters G: Lack of cyclin D-Cdk complexes in Rb-negative cells correlates with high levels of p16INK4/MTS1 tumour suppressor gene product. EMBO J 14: 503-511, 1995.

33. Schauer IE, Siriwardana S, Langan TA and Sclafani RA: Cyclin D1 overexpression vs. retinoblastoma inactivation: implications for growth control evasion in non-small cell and small cell lung cancer. Proc Natl Acad Sci USA 91: 7827-7831, 1994. 